\title{
The effects of global changes upon regional ozone pollution in the United States
}

\author{
J. Chen ${ }^{1, *}$, J. Avise ${ }^{1, * *}$, B. Lamb ${ }^{1}$, E. Salathé ${ }^{2}$, C. Mass ${ }^{2}$, A. Guenther ${ }^{3}$, C. Wiedinmyer ${ }^{3}$, J.-F. Lamarque ${ }^{3}$, S. O'Neill ${ }^{4}$, \\ D. McKenzie ${ }^{5}$, and N. Larkin ${ }^{5}$ \\ ${ }^{1}$ Washington State University, Pullman, WA, USA \\ ${ }^{2}$ University of Washington, Seattle, WA, USA \\ ${ }^{3}$ National Center for Atmospheric Research, Boulder, CO, USA \\ ${ }^{4}$ United States Dept. of Agriculture, Natural Resources Conservation Service, Portland, OR, USA \\ ${ }^{5}$ United States Dept. of Agriculture, Forest Service, Seattle, WA, USA \\ *now at: National Research Council Canada, Ottawa, ON, Canada \\ ***now at: California Air Resources Board, Sacramento, CA, USA
}

Received: 12 June 2008 - Published in Atmos. Chem. Phys. Discuss.: 11 August 2008

Revised: 8 January 2009 - Accepted: 8 January 2009 - Published: 16 February 2009

\begin{abstract}
A comprehensive numerical modeling framework was developed to estimate the effects of collective global changes upon ozone pollution in the US in 2050. The framework consists of the global climate and chemistry models, PCM (Parallel Climate Model) and MOZART-2 (Model for Ozone and Related Chemical Tracers v.2), coupled with regional meteorology and chemistry models, MM5 (Mesoscale Meteorological model) and CMAQ (Community Multi-scale Air Quality model). The modeling system was applied for two 10-year simulations: 1990-1999 as a present-day base case and 2045-2054 as a future case. For the current decade, the daily maximum 8-h moving average (DM8H) ozone mixing ratio distributions for spring, summer and fall showed good agreement with observations. The future case simulation followed the Intergovernmental Panel on Climate Change (IPCC) A2 scenario together with business-as-usual US emission projections and projected alterations in land use, land cover (LULC) due to urban expansion and changes in vegetation. For these projections, US anthropogenic $\mathrm{NO}_{\mathrm{x}}\left(\mathrm{NO}+\mathrm{NO}_{2}\right)$ and VOC (volatile organic carbon) emissions increased by approximately $6 \%$ and $50 \%$, respectively, while biogenic VOC emissions decreased, in spite of warmer temperatures, due to decreases in forested lands and expansion of croplands, grasslands and urban areas. A stochastic model for wildfire emissions was applied that projected $25 \%$ higher VOC emissions in the future. For the global and US
\end{abstract}

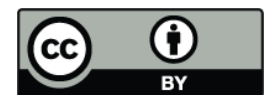

Correspondence to: B. Lamb (blamb@wsu.edu) emission projection used here, regional ozone pollution becomes worse in the 2045-2054 period for all months. Annually, the mean DM8H ozone was projected to increase by $9.6 \mathrm{ppbv}(22 \%)$. The changes were higher in the spring and winter $(25 \%)$ and smaller in the summer $(17 \%)$. The area affected by elevated ozone within the US continent was projected to increase; areas with levels exceeding the $75 \mathrm{ppbv}$ ozone standard at least once a year increased by $38 \%$. In addition, the length of the ozone season was projected to increase with more pollution episodes in the spring and fall. For selected urban areas, the system projected a higher number of pollution events per year and these events had more consecutive days when DM8H ozone exceed 75 ppbv.

\section{Introduction}

Eulerian chemical transport models (CTM) have been widely used to study complex air quality problems for historical pollution events. These models have also begun to be employed as forecast systems to predict air pollution episodes for short term periods (Mckeen et al., 2005; Chen et al., 2008). With increasing concern about the range of impacts due to global change, there are new CTM studies investigating regional air quality impacts from large scale changes (Murazaki and Hess, 2006; Tagaris et al., 2007; Racherla and Adams, 2008; Wu et al., 2008). Global changes, including climate change, land use, land cover (LULC) alteration, population increases and associated emission changes, can influence regional ozone pollution through complex chemical and

Published by Copernicus Publications on behalf of the European Geosciences Union. 
physical processes. The consequences of future ozone pollution on humans and the environment are described in several recent studies (Knowlton et al., 2004; Bell et al., 2007; Campbell-Lendrum et al., 2007).

Climate change is predicted to have direct impacts on regional meteorology (IPCC, 2007). Changing regional meteorology can affect ozone pollution directly and indirectly. One direct consequence of climate change is the positive feedback between increasing temperatures and increasing ozone formation (Sillman and Samson, 1995). Steiner et al. (2006) and Dawson et al. (2007) found a warmer future climate increases ozone production by increasing PAN (peroxyacetylnitrate) decomposition, and, thereby increasing $\mathrm{NO}_{\mathrm{x}}$ concentrations. Quantitatively, Dawson et al. (2007) estimated that a temperature increase of $2.5^{\circ} \mathrm{K}$ can result in 1 to 3 ppbv increase in ozone levels over the Eastern US. However, a warmer climate can also increase atmospheric water content, which can increase ozone loss by $\mathrm{O}_{3}+\mathrm{HO}_{2} \rightarrow 2 \mathrm{O}_{2}+\mathrm{OH}$ and thus decrease ozone atmospheric lifetimes (Racherla and Adams, 2008).

In addition to influences on ozone chemistry, climate change may also create atmospheric conditions that favor air pollution. By assessing future meteorological patterns with a regional climate model, Leung et al. (2005) found that pollution events will increase in the Western US due to a larger number of stagnation events coupled with higher summer temperatures, higher solar radiation and lower precipitation frequency. Similarly Mickley et al. (2004) and Murazaki and Hess (2006), using different global climate models, concluded that climate change alone can cause longer and more frequent pollution episodes due to decreased frequency and intensity of synoptic frontal passages.

Future changes in anthropogenic and biogenic emissions can also substantially impact regional pollution conditions. In the Special Report on Emission Scenarios (SRES) the Intergovernmental Panel on Climate Change (IPCC) described several socioeconomic scenarios with projected future greenhouse gas and pollution emissions: A1, A2, B1, B2 (Nakićenović, et al., 2000). Although the projections between the scenario families are highly variable, all scenarios foresee global increases in anthropogenic ozone precursors due to population increases and urban expansion. Since tropospheric ozone levels have been steadily increasing over the past century (Marenco et al., 1994; Staehelin et al., 1994), further increases in $\mathrm{NO}_{\mathrm{x}}$ and non-methane volatile organic compound (NMVOC) emissions may exacerbate pollution conditions and pose greater risks to human health and the environment in the future.

Although many recent studies have investigated the effects of individual meteorological parameters or regional emissions upon surface ozone, few have considered the collective effects of global changes on a regional scale. This holistic view is important because of the broad effect that global changes have on ozone chemistry and physics. In this case, we take global change to include the effects of climate change, changes in global anthropogenic precursor emissions consistent with the SRES scenarios, changes in US emissions due to population growth and economic expansion, and alterations in LULC that can affect both meteorological conditions and biogenic emissions important for ozone formation. We also consider the effects of changes in climate that affect the occurrence of wildfires within the US. Together, these different features of global change represent a relatively complete suite of changes that will affect air quality in the US in the future.

In this work, we demonstrate a coupled global and regional CTM framework to study global change consequences on US ozone pollution in 2050s. The methodology accounts for the collective factors influencing ozone: from large scale global climate and global pollution burden, to regional emission variations due to LULC alterations and anthropogenic activity. We first describe the modeling approach in Sect. 2, followed by results and discussion in Sect. 3. A summary and conclusions are presented in Sect. 4. In a companion paper by Avise et al. (2008), this investigation is taken a step further with an attribution analysis of the relative importance of the effects on ozone and $\mathrm{PM}_{2.5}$ due to each individual aspect of global change.

\section{Methods}

The model system consists of one-way coupled global and regional scale models where results from the global models were used to drive regional simulations through spatiotemporal varying boundary conditions. In this dynamic downscaling approach, the global models account for the effects of global change and communicate these changes to the regional scale in terms dynamically changing boundary conditions. In turn, the regional models couple these global conditions to better resolved terrain, land use, and emissions affecting ozone formation and fate within the US. The model downscaling between global and regional models had been recently discussed in the literature (Tong and Mauzerall, 2006; Huang et al. 2008).

The model system was applied for two 10-year periods. The base case, 1990-1999, represents present-day air quality conditions. Results from this simulation are compared with long-term measurements for model evaluation, and as a benchmark for comparison with the future case for 20452054. Long-term simulations were carried out to better represent large-scale signals from global change and to minimize the normal temporal variability. These decade-long simulations represent a large array of environmental conditions driven by the combined global and regional model scenario.

\subsection{Global simulations}

The global models used were the PCM (Parallel Climate Model; Washington et al., 2000), and the MOZART-2 
(Model for Ozone and Related Chemical Tracers version 2; Horowitz et al., 2003). The PCM global climate model provided the gridded climate input data to the MOZART2 chemical model. The global models had a horizontal resolution of $\sim 2.8^{\circ}$ in both latitude and longitude directions and 18 hybrid vertical layers from ground to $\sim 4 \mathrm{hPa}$. The MOZART-2 chemistry-transport model was run with a time step of $20 \mathrm{~min}$ (Lamarque et al., 2005a). The output timesteps for PCM and MOZART-2 were $6 \mathrm{~h}$ and $3 \mathrm{~h}$, respectively.

Global $\mathrm{CO}, \mathrm{NO}_{\mathrm{x}}, \mathrm{SO}_{2}, \mathrm{VOC}$, and $\mathrm{PM}_{2.5}$ emissions for MOZART-2 were based on the Emissions Database for Global Atmospheric Research (EDGAR version 3.2; Olivier et al., 2000) and the Global Emissions Inventory Activity (GEIA: http://geiacenter.org). Global biogenic emissions were generated dynamically using algorithms from Guenther et al. (1995) with variable global vegetation distributions for each decade. Global lightning $\mathrm{NO}_{\mathrm{x}}$ emissions were included, but variations in lightning $\mathrm{NO}_{\mathrm{x}}$ emissions from climate change were found to be small in this model setup (Lamarque et al., 2005b).

Future climate and pollutant environments for the 2050s were based on the IPCC SRES A2 scenario (IPCC, 2001). The A2 scenario represents one of the worst projected global environments among all the scenario families (Nakićenović et al., 2000). It has high atmospheric loading with a steady rate of increase of greenhouse gases and ozone precursor emissions. The average $\mathrm{CO}_{2}$ and $\mathrm{CH}_{4}$ mixing ratios in 2050s are both $\sim 50 \%$ higher compared to the present-day case of $353 \mathrm{ppmv}$ and $1.70 \mathrm{ppmv}$, respectively. Global anthropogenic $\mathrm{NO}_{\mathrm{x}}$ emissions are projected to more than double to $71 \mathrm{Tg}$ nitrogen year ${ }^{-1}$, while global anthropogenic VOC emissions are projected to increase by approximately $60 \%$ to $225 \mathrm{Tg}$ carbon year ${ }^{-1}$.

\subsection{Regional simulations}

The regional Mesoscale Meteorological model version 5 (MM5) (Grell et al., 1994) and the EPA Community Multi-scale Air Quality (CMAQ) modeling system (Byun and Schere, 2006) were used to downscale the PCM and MOZART-2 outputs, respectively. Results from the regional models were hourly pollutant concentrations at $36-\mathrm{km}$ grid resolution over the continental US.

\subsubsection{Regional meteorology}

The Pennsylvania State University (PSU) - National Center for Atmospheric Research (NCAR) mesoscale model (MM5, release 3.6.3) was used as the regional climate model and applied in a one-way nested configuration at $108-\mathrm{km}$ and 36-km grid resolutions (Salathé et al., 2008). PCM to MM5 downscaling was conducted at the 108 -km domain by nudging the MM5 results towards that of PCM at every $6 \mathrm{~h}$ time step; no nudging was applied to the $36-\mathrm{km}$ domain, allowing mesoscale features to develop freely. The model runs were conducted in non-hydrostatic mode with the MRF planetary boundary layer scheme (Hong and Pan, 1996), simple-ice cloud microphysics, Kain-Fritsch cumulus parameterization (Kain and Fritsch, 1990), and CCM2 radiation scheme. The model configuration for the future case was identical to the base case except for projected LULC changes.

It is important to consider future LULC alterations in a comprehensive global change scenario. Most previous studies on global change impacting regional air quality have assumed static LULC in the future scenario. LULC variations can significantly influence regional meteorology and air quality through surface-atmosphere energy flux perturbations (Civerolo et al., 2000; McDonald-Buller et al., 2001; Grossman-Clarke et al., 2005). In addition, LULC changes can directly influence the magnitude and spatial distribution of emissions.

Future LULC applied here followed the A2 climate conditions with data prepared for the Community Land Model (CLM; Bonan et al., 2002) and urban expansion information projected from the Spatially Explicit Regional Growth Model (SERGOM; Theobald, 2005). The SERGOM provided urban and suburban population density distributions for 2030. Future vegetation and agriculture LULC were based on a preliminary mapping of plant functional type distributions for the CLM ( Feddema, J., personal communication, 2007). The maps were from an interpolation of the Integrated Model to Assess the Global Environment (IMAGE v2.2; Alcamo et al., 1998; Nakićenović et al., 2000; RIVM, 2002; Strengers et al., 2004). Natural vegetation in the future was held constant relative to the present-day land cover dataset, while future agricultural and grazing extents were represented by the IMAGE v2.2 A2 scenario.

Figure 1 depicts the current and future decade LULC, in terms of the USGS categories used in MM5. The predominant changes are the increasing abundances of shrub, grassland, and dry-land crop areas. Large regions of the central US changed from grass and croplands to pasture or dry-land crop. In the southwest, land covers shift from mostly shrub land to sparse vegetation and grassland. In the Pacific Northwest, areas of evergreen forests are transformed to grassland and irrigated crops. Overall, there is complete disappearance of tundra and wooded wetland categories; these are replaced by shrubs, bare vegetation, dry land pasture and urban areas. Although the scenario appears extreme and is dominated by agriculture, these changes provide an upper limit to the impact of LULC on future meteorology, emissions, and air quality.

\subsubsection{Regional air quality}

The CMAQ model (version 4.4) with SAPRC-99 chemistry mechanism (Carter, 1990) was applied for the regional air quality simulations. The model adopted the MM5 terrain 

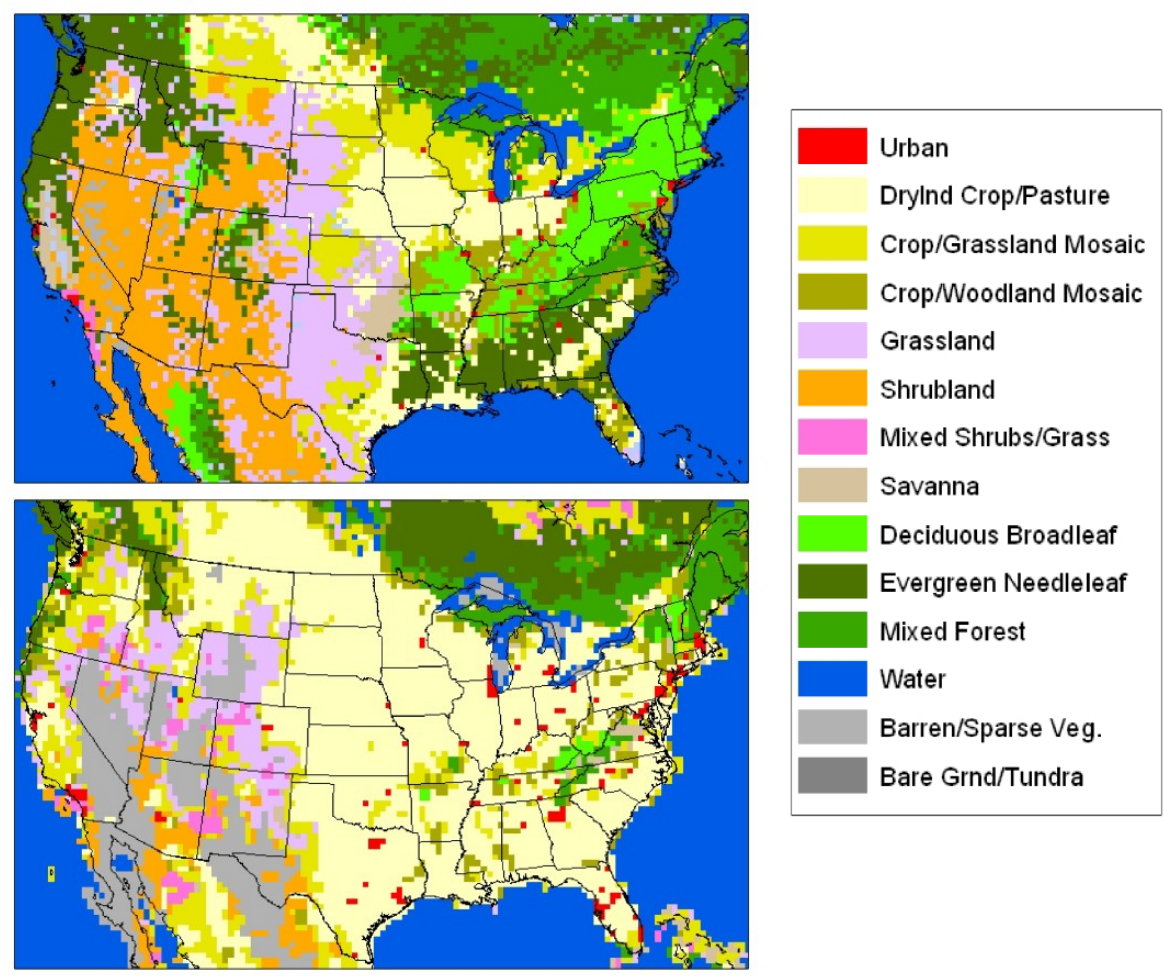

Fig. 1. MM5 land use categories for the 1990s base case (top) and the 2050s future case (bottom).

following coordinates with 17 vertical layers. The top of the first layer was approximately $35 \mathrm{~m}$ above the surface.

Both the base case and future case chemical boundary conditions were downscaled from the MOZART-2 output. Chemical concentrations were taken directly from overlapping grids between the CMAQ lateral boundaries and the MOZART-2 domain. Chemical mechanism species in MOZART-2 were matched to those used in the CMAQ model. The boundary conditions represent the overall global chemical background for each decade. There are considerable differences between the current and projected global chemical conditions. Figure 2 shows the July averaged ozone, $\mathrm{NO}_{\mathrm{x}}$ and VOC profiles along the east and west lateral boundaries. Species concentrations are generally higher for the eastern boundary as the predominant westerly wind brings cleaner Pacific air to the west, while the air mass leaving the eastern boundary contains higher anthropogenic pollution levels.

There is a clear shift towards higher global ozone, $\mathrm{NO}_{\mathrm{x}}$ and VOC pollution in the future. The degree of increase varies vertically. Along the western boundary, the average ozone mixing ratio below $500 \mathrm{mb}$ increased approximately 12 ppbv (31\%), while the VOC mixing ratio almost doubled from 1.1 to $2.1 \mathrm{ppbv}$. Along the east, the ozone mixing ratio was projected to increase by $14 \mathrm{ppbv}(30 \%)$, while $\mathrm{NO}_{\mathrm{x}}$ and VOC mixing ratios were estimated to increase by approximately $50 \%$. The changes on the western edge reflect in- creasing global pollution conditions, while those on the east are due to a combination of global changes and increasing US emissions. Hogrefe et al. (2004) and Avise et al. (2008) found higher global background concentrations to be a primary cause for the increases in US ozone levels in the 2050s. Similarly using a global CTM, Jacob et al. (1999) estimated monthly mean ozone levels in the US to increase by $1-6 \mathrm{ppbv}$ from 1985 to 2010 due to increases in Asian emissions.

\subsubsection{Regional emissions}

Regional emissions for CMAQ were processed with the SMOKE modeling system (Houyoux et al., 2005). The present-day US anthropogenic emission inventory was based on the 1999 EPA National Emission Inventory (available at: http://www.epa.gov/ttn/chief/net/1999inventory.html). The 2050s anthropogenic emissions were projected with the region-specific emission factors base on the EPA Economic Growth and Analysis System (EGAS; US EPA, 2004). Future emissions accounted for estimated population, economic growth and projected energy usage by sector, but did not include emission control regulations or major technology breakthroughs that would significantly affect the use of traditional energy. Future mobile source projections, based on EPA MOBILE6, considered increases in alternative fuel vehicles and decreases in older vehicles; however, the dominant transportation fuels were assumed to remain gasoline and 
Table 1. Summary of domain-wide emissions (kilotons/day) for the base case and the projected emission ratios for the future case (future/current). Biogenic emissions are for the month of July.

\begin{tabular}{lcccccc}
\hline & Area & On-Road Mobile & Non-Road Mobile & Point & Wildfire & Biogenic (July) \\
\hline $\mathrm{CO}$ & $45 / 1.31$ & $185 / 0.98$ & $61 / 1.14$ & $11 / 1.00$ & $1.5 / 1.25$ & - \\
$\mathrm{NO}$ & $5 / 1.57$ & $23 / 0.99$ & $11 / 1.11$ & $23 / 1.00$ & - & $4.1 / 1.02$ \\
$\mathrm{VOC}$ & $24 / 2.01$ & $14 / 0.98$ & $7 / 1.35$ & $5 / 1.00$ & $0.1 / 1.24$ & $156 / 0.66$ \\
$\mathrm{SO}_{2}$ & $3 / 1.52$ & $0.8 / 0.99$ & $1.3 / 1.38$ & $42 / 1.00$ & - & - \\
\hline
\end{tabular}
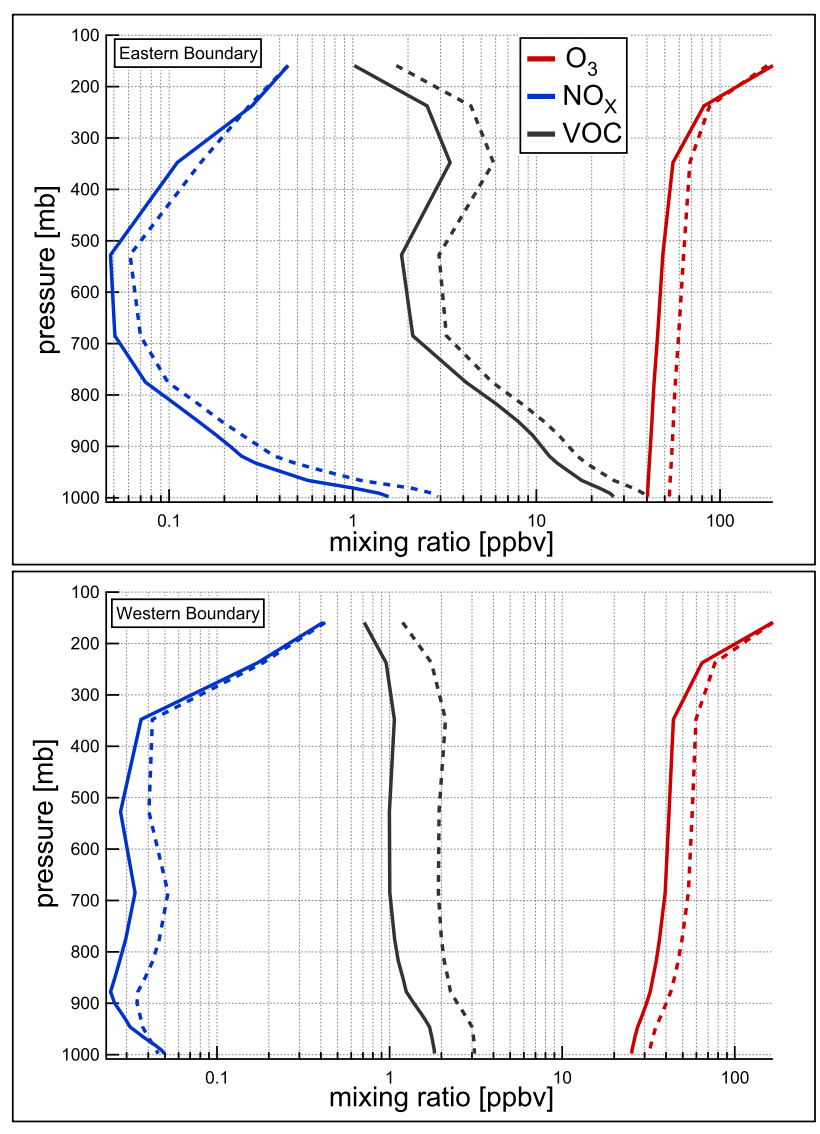

Fig. 2. Base case (solid line) and future case (dotted line) average boundary condition profiles along the western and eastern regional model domain.

diesel. Spatial distributions of future anthropogenic emissions were also updated with population density from the SERGOM to reflect expanding urban areas.

Table 1 shows the regional emission summary for the two cases. The biggest projected change was for area sources with $\mathrm{NO}_{\mathrm{x}}, \mathrm{VOC}$ and $\mathrm{SO}_{2}$ increasing by more than $50 \%$, and $\mathrm{CO}$ increasing by $31 \%$. Non-road mobile emissions were projected to increase between $11 \%$ and $38 \%$ depending on the species, but on-road mobile emissions were projected to stay relatively constant. Anthropogenic point sources were assume unchanged. Overall, the future US anthropogenic
VOC, $\mathrm{NO}_{\mathrm{x}}$ and $\mathrm{CO}$ emissions were projected to increase by $53 \%, 6 \%$ and $6 \%$, respectively, compared to the present-day estimates.

Natural source emissions from vegetation and wildfire were included in the regional domain in both cases. Biogenic emissions were generated dynamically with the MEGAN model (Guenther et al., 2006). The model estimates hourly isoprene, monoterpene and other biogenic VOC emissions from vegetation using a seasonal varying vegetation dataset and hourly meteorology. Present-day vegetation data were from satellite observations. Future case LULC data were based on the same data as that used in the MM5 model described earlier (Fig. 1).

Large differences in biogenic emissions were projected for the future due to changes in LULC and climate. Figure 3 shows the July-averaged isoprene emission comparison normalized at $30^{\circ} \mathrm{C}$. Isoprene emission capacity was projected to decrease because of projected LULC changes.

Isoprene-dominant LULC categories, such as broadleaf forests, were greatly reduced in the southeast, coastal California and northern Midwest, and replaced by grasslands or crops with lower isoprene and monoterpene emission capacity. The reductions were significant since regional isoprene emissions decreased, even though average temperatures were estimated to be warmer. The July biogenic VOC emissions in 2050 s were predicted to decrease by $34 \%$ from the presentday estimates. This is a significant difference in our simulations in comparison to other model studies that projected higher isoprene emissions in the future due to warmer climate (e.g., Hogrefe et al., 2004; Racherla and Adams, 2008; $\mathrm{Wu}$ et al., 2008). Our results show that future increases in biogenic VOC emissions due to warmer temperatures could be offset by reductions in emission capacity due to LULC alterations. Although the LULC applied here represent an extreme scenario with large uncertainty, this change emphasizes the importance of developing reasonable LULC projections for both forested lands and agricultural expansion or contraction.

Emissions from fire events can contribute significant amounts of pollutant precursors and pollutants to the atmosphere (Miranda, 2004; Malm et al., 2004). To account for the impact of biomass burning on air quality, we applied the Bluesky model system (Larkin et al., 2008) to estimate fire emissions for current and future case simulations. Fire event 


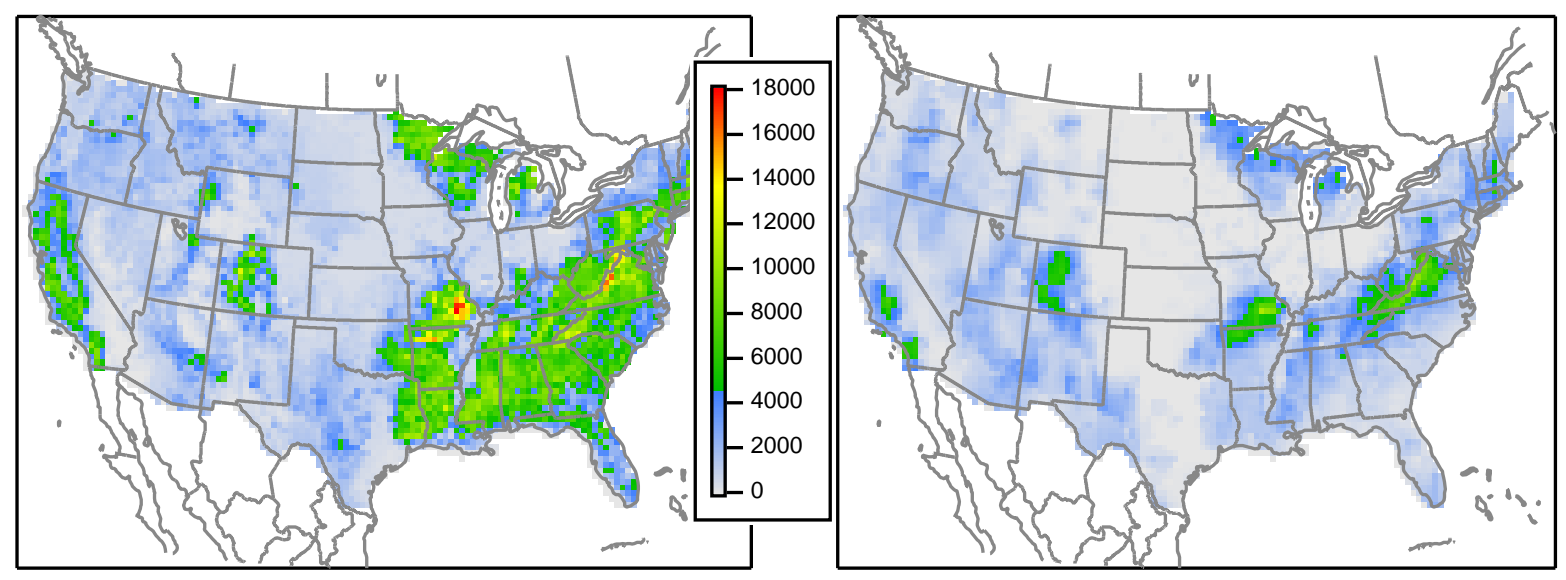

Fig. 3. July isoprene emission capacity normalized to $30^{\circ} \mathrm{C}\left(\mu \mathrm{g} \mathrm{m}^{-2} \mathrm{~h}^{-1}\right)$ for the base case (left) and the future case (right).

data for 1990-1999 were obtained from the Bureau of Land Management with records of fire location and size on federal lands. Future fire events were modeled using the Fire Scenario Builder (FSB) stochastic model (Mckenzie et al., 2006). The FSB model estimates fire occurrence probability, fire size, and fuel consumption with simulated future meteorology from MM5. The Bluesky model projected approximately $25 \%$ increases in VOC and CO emissions from wildfire due to increases in future wildfire activity (Table 1).

\section{Results and discussion}

\subsection{Compare regional meteorology with observations}

Since the simulations were performed using a free-running climate model, without any assimilation of observational data, the results for the current case do not correspond to any specific calendar event, but represent a general realization of current climate conditions. Thus, comparisons of the base case with observations were conducted with an emphasis on the ability of the model to reproduce the frequency and spatial distributions of meteorological parameters and pollutant levels. Surface temperature and precipitation from the MM5 model were compared with station observations across the US for 1990-1999. The evaluations were performed at the station level, independent of year. Observational data were from the Historical Climate Network (HCN; Karl et al., 1990). There were 1221 stations selected for the evaluation, such that all were at elevations within $150 \mathrm{~m}$ of the collocated MM5 model grid cell.

A composite 1990-1999 annual cycle of daily maximum temperature $(T \max )$ and daily minimum temperature ( $T$ min) were computed for MM5 and HCN observations on a monthly interval. Figure 4 compares the simulated and observed results in simple scatter plots, with each point representing a single station and calendar month; calendar months
Table 2. Model performance statistics comparing base case modeled and measured ozone mixing ratios for spring (MAM), summer (JJA) and fall (SON). Average ozone condition indicates averaged monthly daily maximum $8 \mathrm{~h}$ (DM8H) ozone mixing ratios. Episodic ozone condition indicates the monthly top 98 th percentile $8 \mathrm{~h}$ ozone mixing ratios.

\begin{tabular}{lccc}
\hline Average Ozone Condition & & & \\
& Spring & Summer & Fall \\
\cline { 2 - 3 } Number of Points & 2851 & 3066 & 2727 \\
MB (ppbv) & 2.3 & 8.0 & 1.1 \\
ME (ppbv) & 5.2 & 9.7 & 5.9 \\
NMB & $5 \%$ & $15 \%$ & $3 \%$ \\
NME & $11 \%$ & $18 \%$ & $15 \%$ \\
Modeled Average (ppbv) & 51 & 63 & 41 \\
Measured Average (ppbv) & 48 & 55 & 40 \\
R & 0.48 & 0.58 & 0.45 \\
& & & \\
Episodic Ozone Condition & & & \\
Number of Points & 2851 & 3066 & 2727 \\
MB (ppbv) & -1.8 & 3.5 & -2.1 \\
ME (ppbv) & 7.7 & 9.8 & 11 \\
NMB & $-2 \%$ & $4 \%$ & $-1 \%$ \\
NME & $10 \%$ & $11 \%$ & $15 \%$ \\
Modeled Average (ppbv) & 75 & 92 & 74 \\
Measured Average (ppbv) & 76 & 89 & 76 \\
R & 0.46 & 0.59 & 0.30 \\
\hline
\end{tabular}

are distinguished by different colors. Spatial correlations between model and observations are good for all times of the year. The monthly correlation coefficient for $T \max$ are $0.88-0.98$, and for $T \mathrm{~min}$ are $0.91-0.95$. There is a cold bias to $T$ max less than $4^{\circ} \mathrm{C}$ in the summer and a warm bias to $T$ min in the winter less than $5.8^{\circ} \mathrm{C}$. The overall results show the model is capable of correctly representing regional 

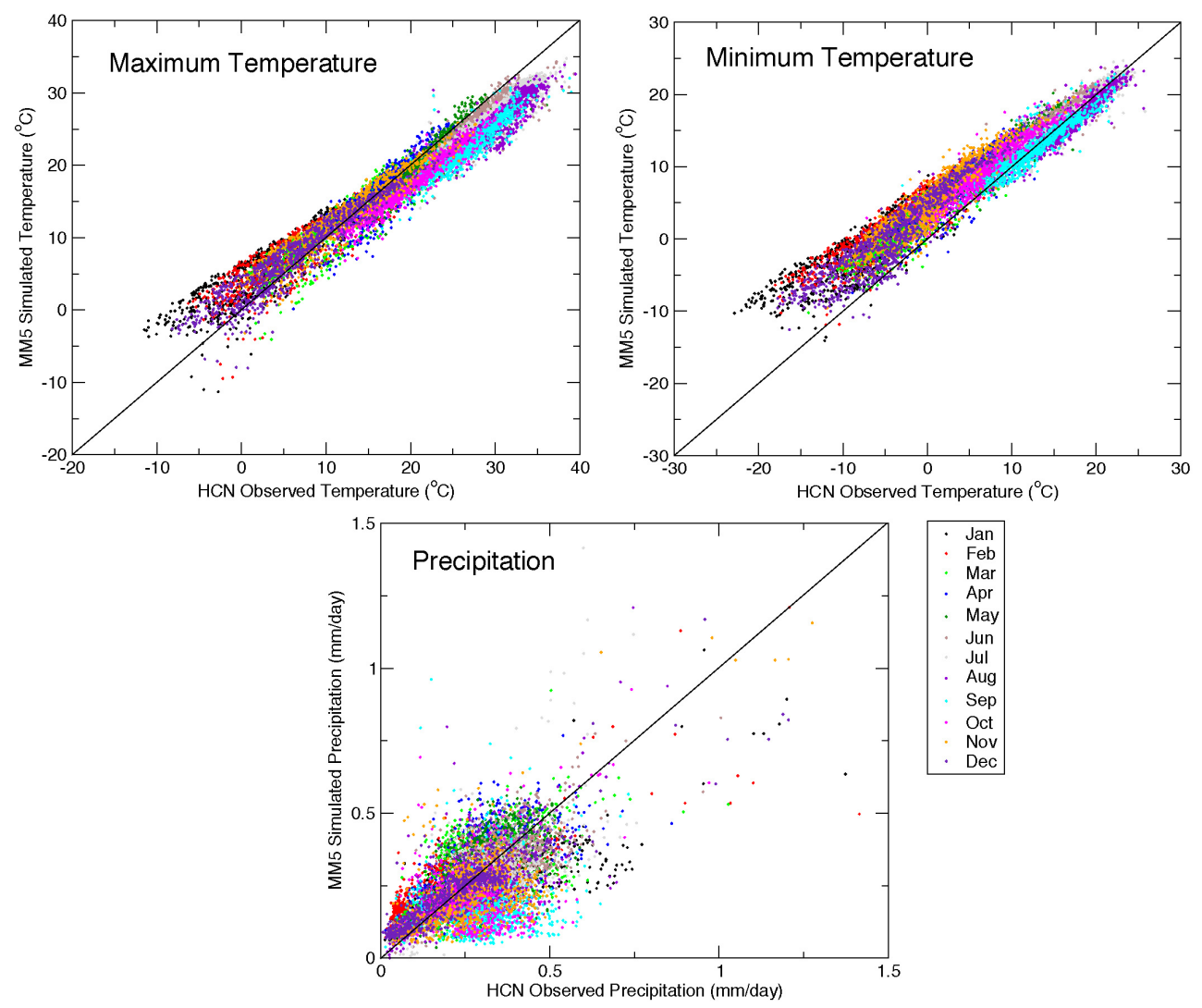

Fig. 4. Scatter plots of MM5 modeled and measured monthly averaged (a) daily maximum temperature, (b) daily minimum temperature, and (c) daily accumulated precipitation by station for 1990-1999.

temperatures, however, there is a reduced diurnal range in the simulation as noted by deviations from the one-to-one line.

Similar comparisons were conducted for modeled precipitation (Fig. 4). Spatial correlation across the continental US is good for winter months, but poor for fall with mixed performance for summer and spring. The annual spatial correlation coefficient is 0.61 with monthly ranges between 0.11 and 0.89 . There is a substantial wet bias in the simulation for summer and fall, with smaller dry bias for winter and spring. The annual mean precipitation bias over the decade is $-0.019 \mathrm{~mm} \mathrm{day}^{-1}$. Spatially, the MM5 simulations tend to overestimate precipitation in the Southwestern US and underestimate in the southeast.

\subsection{Compare modeled ozone with observations}

Long-term hourly ozone measurements were obtained from the EPA Air Quality System (AQS) database for years 19942003 (available at: http://www.epa.gov/ttn/airs/airsaqs). Model comparisons were performed for spring (March, April, and May), summer (June, July, and August) and fall (September, October, and November). The comparisons were not carried out for winter due to a lack of ozone measurement data. Hourly ozone measurements from ap- proximately 1000 sites were used in the comparisons. Stations were grouped geographically by the various US EPAdesignated regions. For simplification, stations in Regions 1, 2 and 3 are grouped together to represent the northeast (Fig. 5). Table 2 summarizes the comparisons using standard model performance statistics (defined in Table 3). The statistics were computed for monthly averaged ozone levels as well as episodic ozone levels paired by measurement sites. The average ozone condition is defined as averaged daily maximum 8-h (DM8H) ozone at individual sites, and the episodic ozone condition is defined as the monthly 98th percentile mixing ratio.

In general, the base case simulation adequately represented the spatial distribution and magnitudes of present-day ozone conditions. The model monthly DM8H ozone mixing ratios were all within a factor of 1.5 of the measured mixing ratios. The correlation coefficients ranged from 0.5 in the spring and fall to 0.6 in the summer. In terms of performance statistics, the normalized mean error (NME) ranged from $11 \%$ in the spring to $18 \%$ in the summer. The model performance was slightly better for episodic ozone events. The NME ranged from $10 \%$ to $15 \%$, and the overall mean error (ME) was between $7.7 \mathrm{ppbv}$ and $11 \mathrm{ppbv}$, in the spring and fall respectively. On average, the model over-predicted 


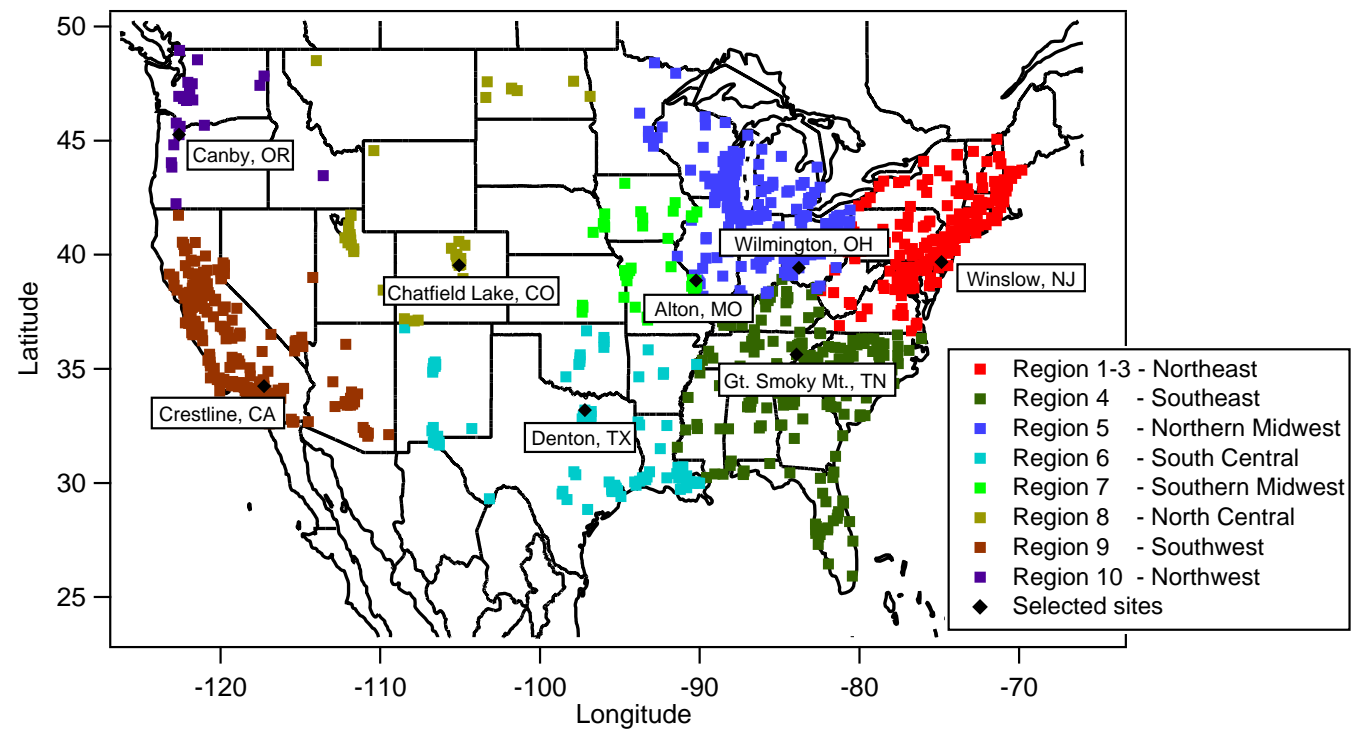

Fig. 5. Locations of the EPA AQS ozone monitoring sites used in the base case model comparison. Sites are color coded by EPA regions. Regions 1, 2, and 3 are treated as a single combined region.
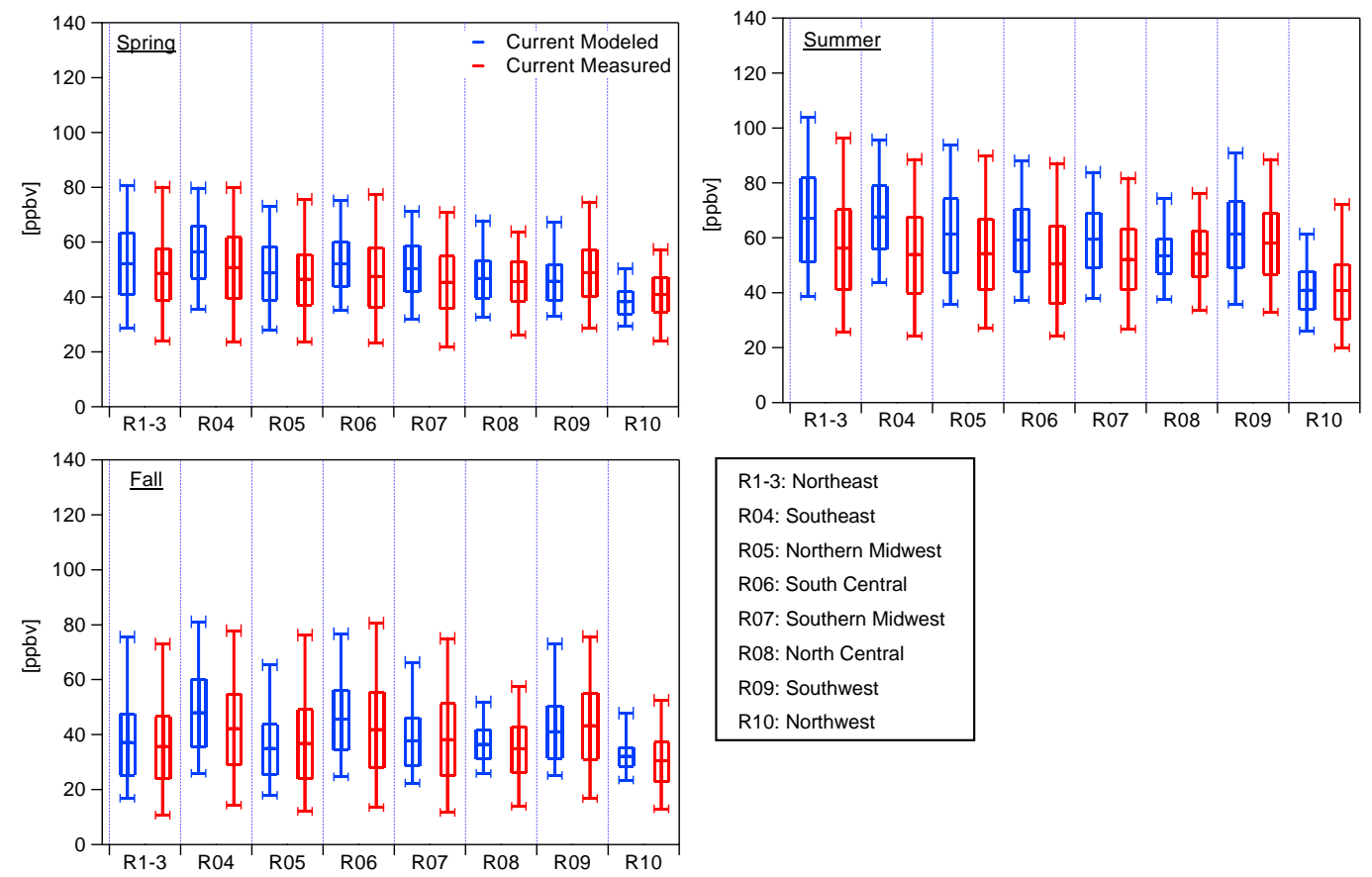

R1-3: Northeast

R04: Southeast

R05: Northern Midwest

R06: South Central

R07: Southern Midwest

R08: North Central

R09: Southwest

R10: Northwest

Fig. 6. Comparison of modeled and measured daily maximum $8 \mathrm{~h}$ (DM8H) ozone mixing ratios for spring, summer and fall by geographic regions. The top and bottom bars represent 98 th and 2 nd percentile values, the top and bottom box indicates 80th and 20th percentile values, and the center bar represents the overall averaged DM8H ozone.

the summer time episodic ozone by $3.5 \mathrm{ppbv}$ and underpredicted the spring and fall episodic ozone by about 2 ppbv.

Figure 6 shows the quantitative regional comparisons of modeled and measured DM8H ozone ranges across measure- ment sites for spring, summer and fall months. In the summer months when ozone mixing ratio was the highest, the average ozone condition was better represented for Western and North central US (R08, R09, and R10) but over-estimated by 
Table 3. Definitions of model performance statistics.

\begin{tabular}{|c|c|}
\hline Number of Paired Data Points & $N$ \\
\hline Mean Bias (MB) & $\frac{1}{N} \sum_{i=1}^{N}\left(M_{i}-O_{i}\right)$ \\
\hline Mean Error (ME) & $\frac{1}{N} \sum_{i=1}^{N}\left|M_{i}-O_{i}\right|$ \\
\hline Modeled average $(\bar{M})$ & $\frac{1}{N} \sum_{i=1}^{N} M_{i}$ \\
\hline Measured average $(\bar{O})$ & $\frac{1}{N} \sum_{i=1}^{N} O_{i}$ \\
\hline Normalized Mean & $\frac{1}{N} \sum_{i=1}^{N}\left(M_{i}-O_{i}\right) / \bar{O} \times 100 \%$ \\
\hline Bias (NMB) (\%) & \\
\hline $\begin{array}{l}\text { Normalized Mean } \\
\text { Error (NME) }(\%)\end{array}$ & $\frac{1}{N} \sum_{i=1}^{N}\left|M_{i}-O_{i}\right| / \bar{O} \times 100 \%$ \\
\hline \multirow[t]{2}{*}{ Correlation Coefficient (r) } & $\sum_{i=1}^{N}\left(M_{i}-\bar{M}\right)\left(O_{i}-\bar{O}\right)$ \\
\hline & {$\left[\sum_{i=1}^{N}\left(M_{i}-\bar{M}\right)^{2} \times \sum_{i=1}^{n}\left(O_{i}-\bar{O}\right)^{2}\right]^{1 / 2}$} \\
\hline
\end{tabular}

$M_{i}$ - Modeled mixing ratio

$O_{i}$ - Measured mixing ratio

7-10 ppbv for Eastern and South central US (R1-3 to R07). The comparison was better for the 98th percentile episodic ozone conditions where mixing ratio differences ranged from a $10 \mathrm{ppbv}$ under-prediction in the Northwestern US (R10) to an 8 ppbv over-prediction in Northeastern US (R1-3). In the spring and fall months, the regional model performances were similar as in the summer, but the regional ozone mixing ratios were lower with narrower ranges. In all seasons the comparisons were poorer for lower ozone conditions. The model generally over-estimated the 20th and 2nd percentile ozone mixing ratios, the positive biases across all regions and months ranged from $0-16 \mathrm{ppbv}$ and 3-20 ppbv, respectively.

\subsection{Future meteorological conditions}

The magnitudes and spatial differences of present-day and future case average daily maximum surface temperature ( T max), boundary layer height (PBL) and daily accumulated precipitation were compared by month and for the summer season (Fig. 7). The annual averaged $T$ max was projected to increase by $+1 \cdot 3^{\circ} \mathrm{C}$. Monthly differences varied from $+0.2^{\circ} \mathrm{C}$ in November to $+2.0^{\circ} \mathrm{C}$ in September. The spatial distribution for the summer shows $T$ max in the east and southwest increased by up to $4^{\circ} \mathrm{C}$. Regions in the Pacific Northwest and southeast showed smaller increases of $+2^{\circ} \mathrm{C}$. $T$ max in the central states was predicted to have little change with small regions in the northern Texas showing decrease of $-0.5^{\circ} \mathrm{C}$. Changes in summer PBL heights show good spatial correlation with $T$ max. Regions with decreases or small increases in temperature have lower PBL heights, while regions with larger temperature increases have higher PBL in the future. Annually the mixing height was projected to increase by $60 \mathrm{~m}(2 \%)$; however, the monthly variations differed from $32 \mathrm{~m} \mathrm{(2 \% )} \mathrm{lower} \mathrm{in} \mathrm{December} \mathrm{to} 125 \mathrm{~m}(5 \%)$ higher in April. Since the spatial correlation for PBL and temperature is high, future increases in ozone pollution that result from higher temperature may be somewhat offset by the higher PBL heights.

The projected changes in daily accumulated precipitation were very small. Rainfall was projected to be slightly higher $(+0.2 \mathrm{~mm})$ in the spring but lower for the rest of the year $(-0.1 \mathrm{~mm})$. The magnitude of change was larger at the regional scale. Precipitation in the summer was projected to be higher in the central states, but decreased slightly for the southwest, Eastern Texas and coastal Florida. Higher precipitation and associated cloud cover can decrease photolysis rates and increase removal of ozone through wet deposition, thereby reducing ozone levels.

\subsection{Future ozone pollution conditions}

The collective effects of global and regional changes were projected to cause poorer air quality in the US. The magnitudes of pollution changes varied spatially and temporally Fig. 8 shows the spatially averaged DM8H ozone comparisons by month and over the entire year. The annual DM8H ozone in the US was projected to increase by $+9.6 \mathrm{ppbv}$ (22\%) from the base case of $44 \mathrm{ppbv}$. The inter-annual ozone variability was similar for the current and the future cases: the 10-year DM8H ozone standard deviations for the base case and the future case were $10 \mathrm{ppbv}$ and $11 \mathrm{ppbv}$, respectively. The annual DM8H ozone standard deviations were larger than the monthly values of $3-5$ ppbv because ozone mixing ratios are higher during summers but lower during the rest of the months.

Future monthly averaged DM8H ozone mixing ratios were projected to be higher in all months by between +8 and +13 ppbv. The rate of increase was larger in the winter and spring than the rest of the year. In the winter and spring, the projected DM8H ozone increased by $28 \%$, while in the summer months it increased by $17 \%$. The differences are attributed to higher future chemical boundary conditions as well as decreases in PBL height during the winter. In a separate attribution study of factors contributing to future US ozone, Avise et al. (2008) show that for the A2 

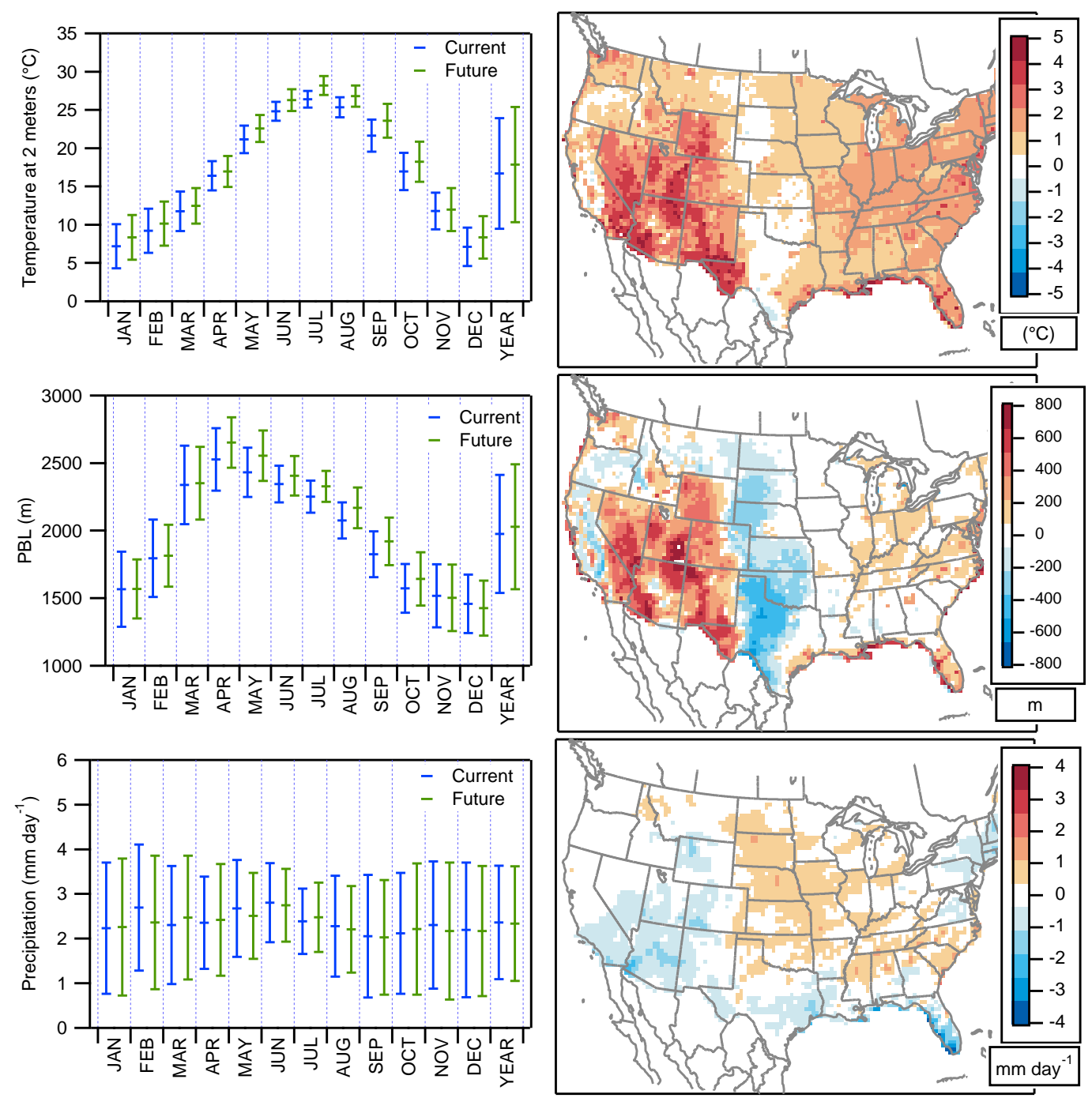

Fig. 7. (Left) US continental monthly and annually averaged daily maximum surface temperature, PBL height and daily accumulated precipitation. The error bars indicate the standard deviation of daily values over the 10-year simulations. (Right) Difference plots of the corresponding variable over the summer months (future case minus base case).

scenario, increasing tropospheric pollution levels, incorporated as chemical boundary conditions, have the most significant impact compared to changes in future US emissions, US meteorology, or regional LULC.

The overall projected DM8H ozone increase of $+9.6 \mathrm{ppbv}$ (22\%) in 2050s from global change is slightly higher than those reported in other recent studies using CTM downscaling (Hogrefe et al., 2004; Steiner et al., 2006; Tagaris et al., 2007; Tao et al., 2007). This discrepancy is likely due to different considerations in future chemical boundary conditions and future US emissions. None of the above studies considered future chemical boundary conditions with a dynamic global chemistry model. The studies also did not account for the associated LULC changes due to future climate, and they projected US emissions based on IPCC scenario factors or assumed future emission reductions with successful emission policies and controls. In this work, chemical boundary conditions were derived from the global MOZART-2 model, US vegetation distribution were altered following the IPCC A2 scenario, and US anthropogenic emissions were projected to increase based on economic and population growth factors. The results presented here can therefore be taken as an upper bound on projected US air quality for 2050 . However, it is important to note that the ozone difference may have been greater if LULC were to remain unchanged with higher biogenic emissions as the result of a warmer climate.

The projected poorer ozone air quality in the future was also reflected in the average number of days when ozone exceeds the new US EPA ambient air quality standard of 75 ppbv (Fig. 9). Episodic ozone events were projected to 


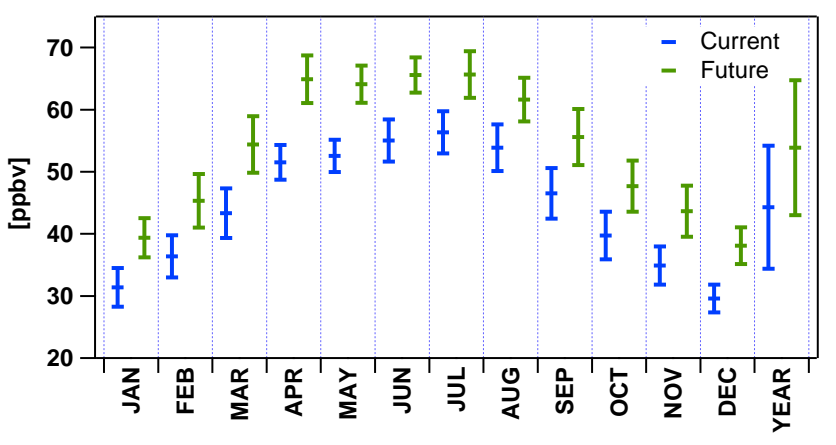

Fig. 8. Comparison of current and future case continental averaged daily maximum $8 \mathrm{~h}(\mathrm{DM} 8 \mathrm{H})$ ozone distributions. The top and bottom bars represent the standard deviations over the 10-year simulation. The middle bar indicates the overall month and annual averaged DM8H ozone.

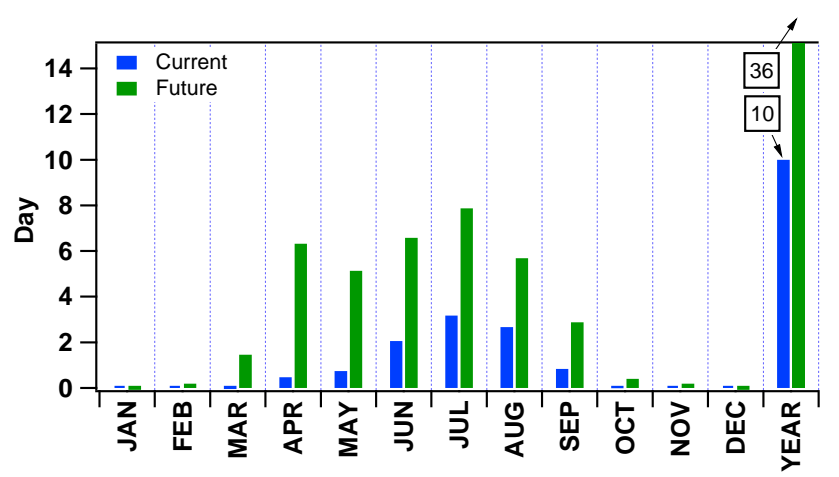

Fig. 9. Spatial averaged number of days per month and per year that daily maximum $8 \mathrm{~h}(\mathrm{DM} 8 \mathrm{H})$ ozone mixing ratio exceeds $75 \mathrm{ppbv}$.

occur more frequently in all months except the winter. The largest increase in episodic ozone frequency occurred in the spring. Annually, episodic ozone days were projected to increase more than 3 times from the base case of 10 days per year. In the summer, the average ozone episode frequency was projected to increase to approximately 6.7 days from the base case of 2.6 days per year. Since ozone attainment is determined by the 4th highest annual DM8H ozone averaged over 3 years, increasing the frequency of ozone exceeding $75 \mathrm{ppbv}$ on an annual basis will increase the likelihood of regions violating the ozone standard.

Under the combined impacts of global change, the ozone pollution season was projected to be longer, with diminished seasonal difference between the spring and summer months (Fig. 9). In the 2050s, the average US ozone season was projected to start as early as March and end in October. In both the base case and the future case, ozone events occur most frequently in July when surface temperature was also the highest.
3.5 Future ozone pollution by regions and sites

Figure 10 shows the difference map of average DM8H ozone mixing ratio for the summer months (future case minus the base case). The spatial distribution correlated with the projected increases in summer surface temperature as well as decreases in summer precipitation (Fig. 4). Higher ozone levels were projected across the continent with larger increases in the east, south and southwest.

The combined effects of higher global and US emissions, expansion of urban areas, and warmer summer temperatures will potentially cause much of the US to experience higher ozone condition in the future. Many urban areas, where ozone is more sensitive to VOC emissions, were projected to have summer DM8H ozone increases between $+10 \mathrm{ppbv}$ to +20 ppbv (Fig. 10). The summer DM8H ozone mixing ratios in rural regions were also projected to be higher by approximately +2 ppbv to +10 ppbv in the 2050s. The differences in ozone changes are due to combinations of changes in local emissions and environmental conditions as well as due to collective global changes. There were, however, isolated locations where episodic DM8H ozone mixing ratios were projected to decrease in 2050s. Most of these represent major cities such as Washington, DC, New York, NY, and Los Angeles, CA. The projected decreases of 1 to 3 ppbv are likely due to local increases in $\mathrm{NO}_{\mathrm{x}}$ emissions such that fresh $\mathrm{NO}_{\mathrm{x}}$ emissions enhance ozone chemical removal via NO titration. Similar occurrences were found by Civerolo et al. (2007) for the New York area. By using a regional CTM with the IPCC A2 scenario, they estimated ozone in New York urban centers in the 2050s to decrease by 1 to $1.2 \mathrm{ppbv}$ due to future urbanization, which resulted in higher anthropogenic emissions and reduced biogenic emissions.

Spatial comparisons also showed future ozone pollution to impact more areas within the US. Quantitatively, of the 6094 domain grids representing the contiguous US, 86\% were projected to have DM8H ozone exceeding the $75 \mathrm{ppbv}$ standard at least once per year, and $76 \%$ were to exceed the standard by at least four times per year. This represents a $38 \%$ increase in areas experiencing high ozone levels compared to the base case, and the possibility of $79 \%$ increase in areas that were designated as non-attainment with the federal ozone standard. Larger fractions of rural regions were projected to have high ozone conditions in 2050s. Most of these occurrences were in spring and summer months when conditions are favorable to ozone chemistry.

Figure 11 shows the quantitative seasonal comparisons of base case and future case DM8H ozone averaged by the measurement sites shown in Fig. 5. Across the regions, the average DM8H ozone were estimated to increase by $9-15 \mathrm{ppbv}$ in the spring and 6-13 ppbv in the summer. The south central US (R06) had the largest ozone increase compare to the base case, with $15 \mathrm{ppbv}(+29 \%)$ and $13 \mathrm{ppbv}(+22 \%)$ increases, respectively for spring and summer months. In contrast, the Northwestern US (R10) had the least amount of change with 


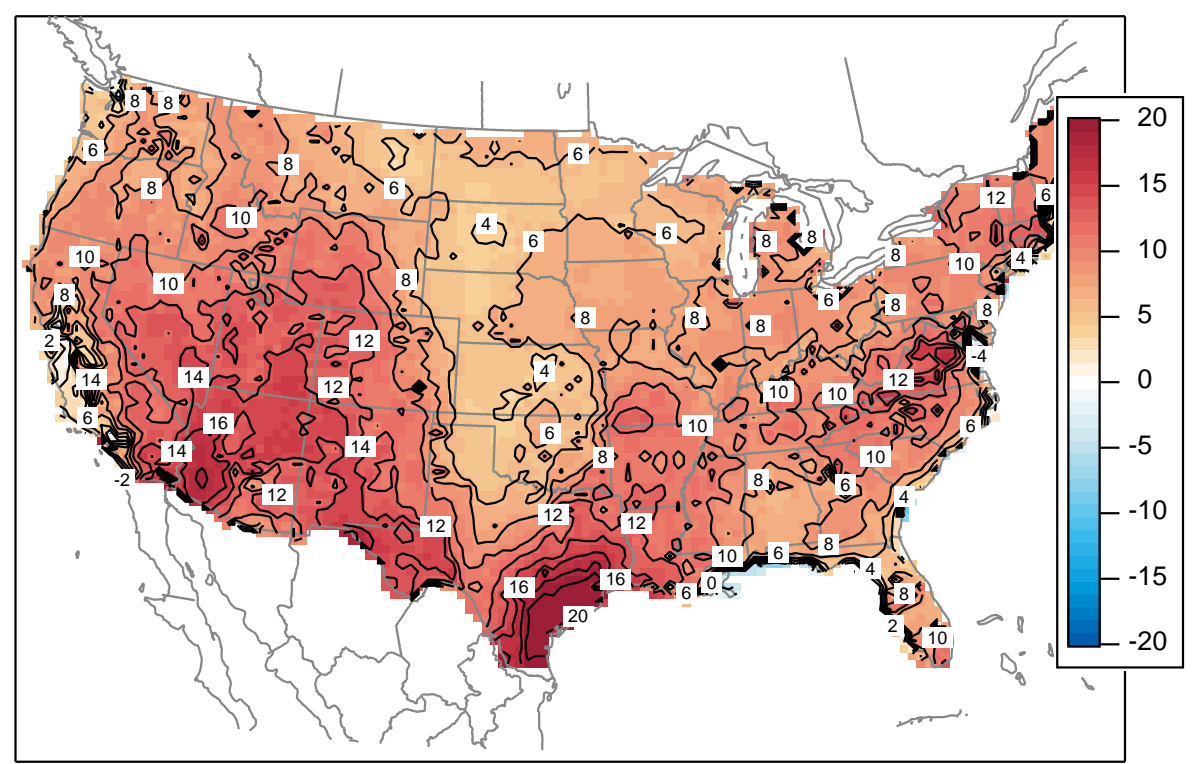

Fig. 10. Difference plot of summer averaged daily maximum $8 \mathrm{~h}$ averaged (DM8H) ozone mixing ratios (ppbv) (future case minus base case).
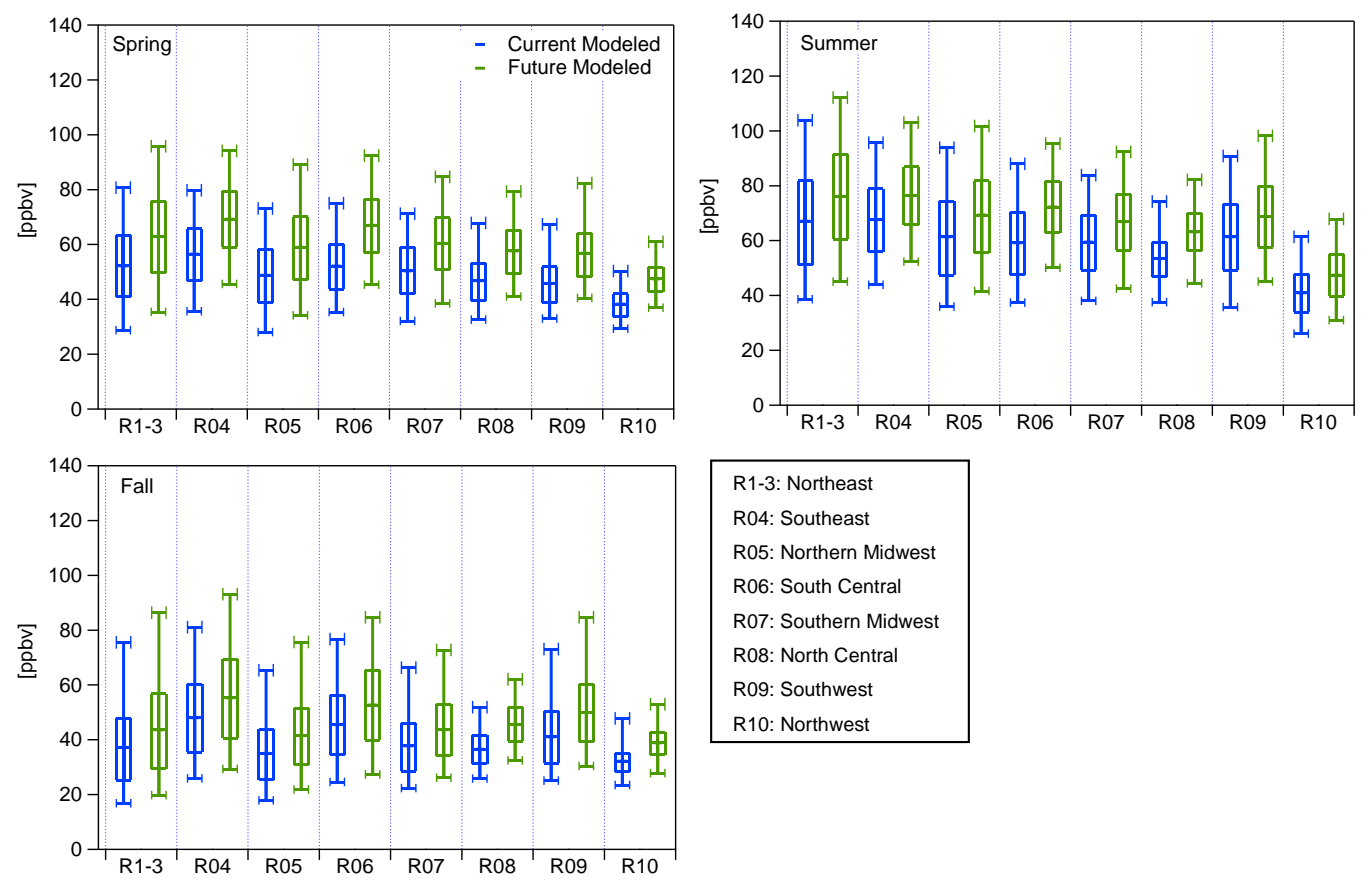

\begin{tabular}{l} 
R1-3: Northeast \\
R04: Southeast \\
R05: Northern Midwest \\
R06: South Central \\
R07: Southern Midwest \\
R08: North Central \\
R09: Southwest \\
R10: Northwest \\
\hline
\end{tabular}

Fig. 11. Comparison of current modeled and future modeled daily maximum $8 \mathrm{~h}$ (DM8H) ozone mixing ratios for spring, summer and fall by geographic regions. The top and bottom bars represent 98 th and 2 nd percentile values, the top and bottom box indicates 80 th and 20 th percentile values, and the center bar represents the overall averaged DM8H ozone.

9 ppbv (+24\%) and $6 \mathrm{ppbv}(+16 \%)$ increases. In the fall season, the regional changes were more homogeneous between $6 \mathrm{ppbv}$ and $9 \mathrm{ppbv}$. The Southwestern US (R08) had the largest estimated increase of $+25 \%$ from the base case of $37 \mathrm{ppbv}$, and the southern Midwest region (R07) had the least amount of change, with $6 \mathrm{ppbv}(+16 \%)$ increase from the base case of 38 ppbv. 
The regional ozone spatial variability, measured by ozone mixing ratio standard deviations across measurement sites, was projected to be smaller in the future case. The smaller variability implies that ozone concentrations in the 2050s were projected to have smaller spatial differences between sites within a region. This is likely due to expansions of urban areas with more homogeneous LULC and pollution responses.

Eight sites were selected across the regions to compare the impacts of global change on ozone (Fig. 5). These sites were chosen for their high observed ozone during 1992-2003. Each site is downwind of a large urban area with average measured episodic ozone levels ranging from $84 \mathrm{ppbv}$ in Canby, OR to $165 \mathrm{ppbv}$ in Crestline, CA. Ozone seasons at these locations, measured by days per month DM8H ozone exceeding $75 \mathrm{ppbv}$, were projected to lengthen. The changes were larger for cities in the east and in California compared to the rest of the sites. In the present-day, most sites had ozone seasons between April and September, except Chatfield Lake, CO and Canby, OR where the ozone season was shorter from May to August. In the future case, all sites were projected to have longer ozone seasons. The three sites in the east, Winslow, NJ, Gt. Smoky Mt., TN, and Wilmington, $\mathrm{OH}$, were projected to have the longest ozone season. Ozone season in these sites were projected to start as early as February and end in November with an average 0.3 days and 0.4 days per month when DM8H ozone exceeds 75 ppbv, respectively. Chatfield Lake and Canby with least number of episodic ozone days had shorter ozone season from April to September. For the rest of the sites, high ozone conditions were projected to occur from March through October.

In the 2050s, many areas were projected to have more frequent ozone episodes with longer pollution durations. Figure 12 shows the normalized percentage of ozone events grouped by number of consecutive days when DM8H ozone mixing ratios exceed 75 ppbv. The total ozone episode-day in each case, defined as number of days ozone mixing ratio exceed $75 \mathrm{ppbv}$ at a site, is noted on the figure legend. In the base case, most sites had less frequent and shorter ozone episodes. At seven of the sites, more than $50 \%$ of all episodes were shorter than 2 consecutive days.

In the future case, all 8 sites were projected to have decreased frequency of one- and two-day episodes, in exchange were higher frequency of longer pollution events. The shift in episode length distribution is due to normalization by total ozone episode-day from each decade. In the future case, the model estimated a shift in percentage of shorter-duration episodes in exchange for increased number of longer-duration episodes. The actual number of episodeday in the future is higher due to higher total number of ozone episodes. Except for Chatfield Lake, CO and Canby, OR more than $35 \%$ of ozone episodes were projected to last more than 3 consecutive days, compared to approximately $20 \%$ in the base case. The possibility of more frequent and prolonged exposures to high ozone conditions in the future is likely to cause more damaging effects on human health than single-day acute exposures (Spektor et al., 1991; Ratto et al., 2006).

\section{Summary and conclusions}

We have implemented a numerical modeling system to quantify regional ozone pollution 50 years in the future and accounted for the combined effects of large-scale global change, regional-scale emissions, LULC changes within the US and changes in wildfire occurrence. The model framework includes a coupled global and regional model system where the PCM and MOZART-2 global models provide spatiotemporal boundary conditions as input to the regional MM5 and CMAQ models. This framework was applied to simulate ozone conditions for the 1990-1999 base case and the 2045-2054 future case. The projected future global anthropogenic influence follows the IPCC A2 business-asusual scenario. Future US anthropogenic emissions were projected to be higher based upon population and economic growth projections, while biogenic VOC emissions were estimated to be lower due to LULC changes. Wildfire emissions were estimated to be $25 \%$ higher in the future for both VOC and CO.

The base case simulations were compared with long-term meteorology and ozone measurements. Correlations for daily maximum and minimum temperature were good, but the simulation showed reduced diurnal temperature ranges. The system represented the episodic ozone conditions well for spring, summer and fall months, but had positive biases for average and low ozone conditions. Spatially, the system was able to reproduce the measured ozone mixing ratios variations across the US.

Large changes in regional air quality conditions were projected for the 2050s with respect to the base case simulation. Although the estimated changes in LULC reduced the biogenic emissions in the 2050s, the projected increase in anthropogenic emissions and higher tropospheric background pollutant levels caused ozone air pollution to be worse both spatially across the US and temporally within a year. The mean annual DM8H ozone mixing ratio was projected to increase by $9.6 \mathrm{ppbv}$ (22\%) compared to the base case. Monthly DM8H ozone were projected to increase by 8 to $13 \mathrm{ppbv}$ with a larger percentage change in the winter and spring compared to the rest of the year.

Spatially, the projected ozone change varied across the US continent. There were larger increases in the east, south and southwest, and lesser increases in the Pacific Northwest and central states. Quantitatively, 38\% more areas were projected to experience high ozone pollution exceeding the 75 ppbv ozone standard at least once per year compared to the base case.

Temporally, there were more days when DM8H ozone mixing ratios exceed $75 \mathrm{ppbv}$ in the future. The increase in 

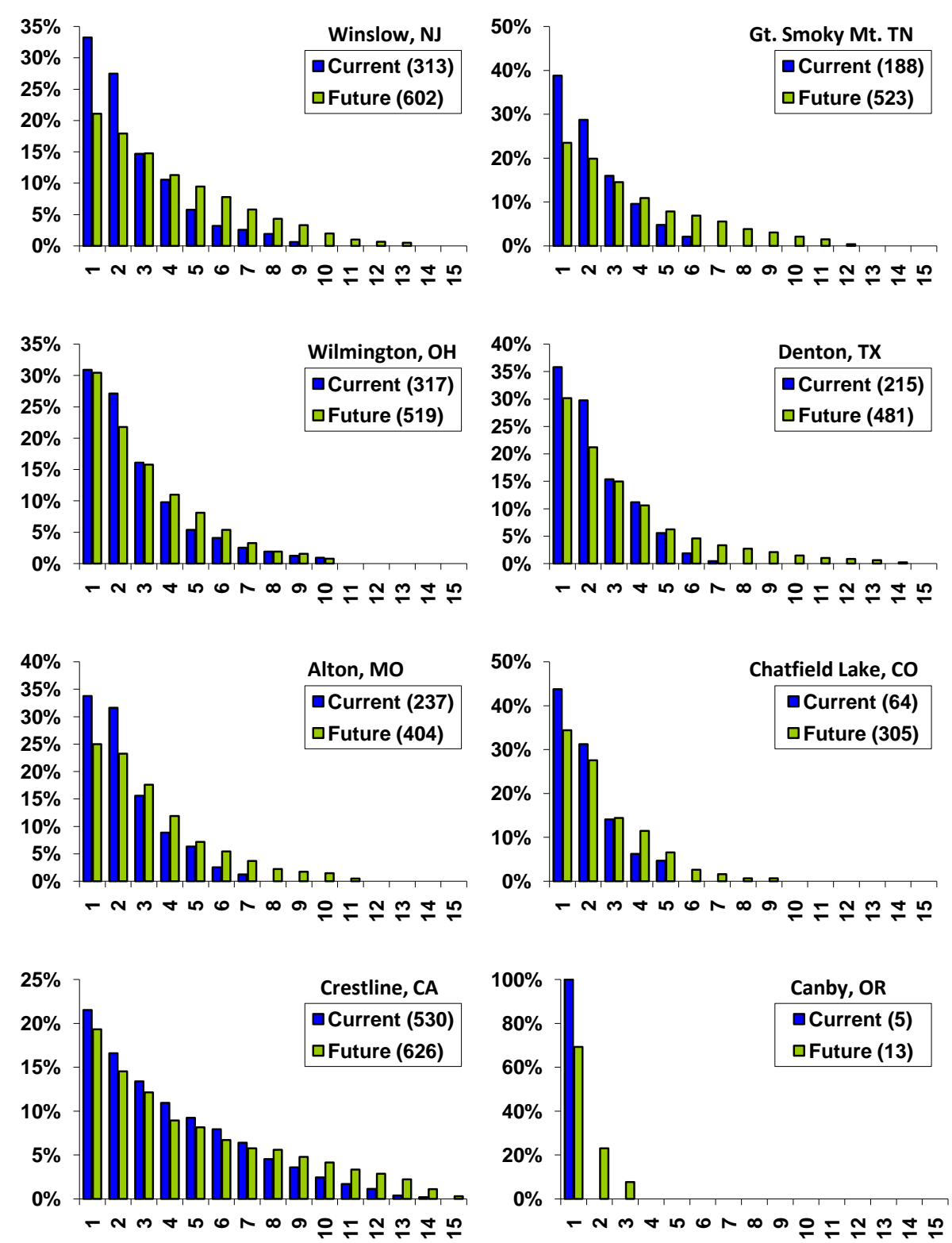

Fig. 12. Frequency distributions of base case and future case ozone episode duration expressed as consecutive days per episode daily maximum $8 \mathrm{~h}$ averaged (DM8H) ozone exceed $75 \mathrm{ppbv}$. Numbers in the legend indicate the total number of ozone episodes within each case.

ozone episode frequency not only occurred during the summer season, as in the base case, but also in the spring and fall due to longer warming periods. The results also showed a higher frequency of longer ozone pollution episodes with more consecutive days having ozone mixing ratios exceed the 75 ppbv standard.

The results presented in this work showed the collective impacts of future global change on regional ozone pollution in the US based on the business-as-usual (A2) climate and pollution scenario in the 2050s. Studies based upon more optimistic climate scenarios and projected future US emission conditions will produce a different range of results. This work provides a potential upper bound on US ozone conditions given the more pessimistic aspect of the scenarios considered.

The large reductions and spatial changes in the projected biogenic emissions demonstrated the sensitivity and uncertainty with projected LULC changes, and their indirect impact on future ozone air quality. The projected ozone magnitude and spatial distribution may have been worse if LULC were to remain unchanged with higher biogenic emissions as the result of a warmer climate. Due to the complexity of atmospheric chemistry and meteorology influences on pollution events, the overall ozone change may result from 
additive or subtractive effects of multiple factors. Additional sensitivity analyses, as presented in Avise et al. (2008), were applied to further isolate and quantify the importance of individual global change variables on future pollution conditions.

Acknowledgements. This work was supported by the US Environment Protection Agency Science to Achieve Results (STAR) grant (Agreement Number: RD-83096201), and partially funded by the Joint Institute for the Study of the Atmosphere and Ocean (JISAO) under NOAA Cooperative Agreement No. NA17RJ1232, Contribution \#1585. The authors would like to thank D. Theobald (Colorado State University) for providing the projected urban and suburban population density distributions, J. Feddema (University of Kansas) for providing the projected landuse and land cover dataset, and L. Buja and G. Strand (National Center for Atmospheric Research) for providing the global PCM output. The Parallel Climate Model project was supported by the Office of Biological and Environmental Research of the US Department of Energy and the Directorate for Geosciences of the National Science Foundation. JFL was supported by the SciDAC project from the Department of Energy. The National Center for Atmospheric Research is operated by the University Corporation for Atmospheric Research under sponsorship of the National Science Foundation.

Edited by: F. J. Dentener

\section{References}

Alcamo, J., Leemans, R., and Kreileman, E.: Global change scenarios of the 21st century. Results from the IMAGE 2.1 model, Pergamon\&Elseviers Science, London, 296 pp., 1998.

Avise, J., Chen, J., Lamb, B., Wiedinmyer, C., Guenther, A., Salathé, E., and Mass, C.: Attribution of projected changes in US ozone and $\mathrm{PM}_{2} .5$ concentrations to global changes, Atmos. Chem. Phys. Discuss., 8, 15131-15163, 2008, http://www.atmos-chem-phys-discuss.net/8/15131/2008/.

Bell, M. L., Goldberg, R., Hogrefe, C., Kinney, P. L., Knowlton, K., Lynn, B., Rosenthal, J., Rosenzweig, C., and Patz, J. A.: Climate change, ambient ozone, and health in 50 US cities, Clim. Change, 82, 61-76, 2007.

Bonan, G. B., Oleson, K. W., Vertenstein, M., Levis, S., Zeng, X. B., Dai, Y. J., Dickinson, R. E., and Yang, Z. L.: The Land Surface Climatology of the Community Land Model Coupled to the NCAR Community Climate Model, J. Climate, 15(22), 31233149, 2002.

Byun, D. and Schere, K. L.: Review of the governing equations, computational algorithms, and other components of the Models3 Community Multiscale Air Quality (CMAQ) modeling system, Appl. Mech. Rev., 59, 51-77, 2006.

Campbell-Lendrum, D. and Corvalań, C.: Climate change and developing-country cities: Implications for environmental health and equity, J. Urban Health, 84, 109-117, 2007.

Carter, W. P. L.: A detailed mechanism for the gas-phase atmospheric reactions of organic-compounds, Atmos. Environ., 24, 481-518, 1990.

Chen, J., Vaughan, J., Avise, J., O’Neill, S., and Lamb, B.: Enhancement and evaluation of the AIRPACT ozone and PM2.5 forecast system for the Pacific Northwest, J. Geophys. Res., 113, D14305, doi:10.1029/2007JD009554, 2008.

Civerolo, K., Hogrefe, C., Lynn, B., Rosenthal, J., Ku, J.-Y., Solecki, W., Cox, J., Small, C., Rosenzweig, C., Goldberg, R., Knowlton, K., and Kinney, P.: Estimating the effects of increased urbanization on surface meteorology and ozone concentrations in the New York City metropolitan region, Atmos. Environ., 41, 1803-1818, 2007.

Civerolo, K. L., Sistla, G., Rao, S. T., and Nowak, D. J.: The effects of land use in meteorological modeling: Implications for assessment of future air quality scenarios, Atmos. Environ., 34, 1615-1621, 2000.

Dawson, J. P., Adams, P. J., and Pandis, S. N.: Sensitivity of ozone to summertime climate in the eastern USA: A modeling case study, Atmos. Environ., 41, 1494-1511, 2007.

Grell, A. G., Dudhia, J., and Stauffer, D. R.: A description of the fifth-generation PennState/NCAR mesoscale model (MM5), NCAR Technical Note NCAR/TN-398+STR, Natl. Cent. Atmos. Res., Boulder, Colo. 138 pp., available at http://www.mmm.ucar. edu/mm5, 1994.

Grossman-Clarke, S., Zehnder, J. A., Stefanov, W. L., Liu, Y., and Zoldak, M. A.: Urban modifications in a mesoscale meteorological model and the effects on near-surface variables in an arid metropolitan region, J. Appl. Meteorol., 44, 1281-1297, 2005.

Guenther, A., Hewitt, C. N., Erickson, D., Fall, R., Geron, C., Graedel, T., Harley, P., Klinger, L., Lerdau, M., Mckay, W. A., Pierce, T., Scholes, B., Steinbrecher, R., Tallamraju, R., Taylor, J., and Zimmerman, P.: A global-model of natural volatile organic-compound emissions, J. Geophys. Res., 100,8873-8892, 1995.

Guenther, A., Karl, T., Harley, P., Wiedinmyer, C., Palmer, P. I., and Geron, C.: Estimates of global terrestrial isoprene emissions using MEGAN (Model of Emissions of Gases and Aerosols from Nature), Atmos. Chem. Phys., 6, 3181-3210, 2006, http://www.atmos-chem-phys.net/6/3181/2006/.

Hogrefe, C., Lynn, B., Civerolo, K., Ku, J. Y., Rosenthal, J., Rosenzweig, C., Goldberg, R., Gaffin, S., Knowlton, K., and Kinney, P. L.: Simulating changes in regional air pollution over the eastern United States due to changes in global and regional climate and emissions, J. Geophys. Res., 109, D22301, doi:10.1029/2004JD004690, 2004.

Hong, S. Y. and Pan, H. L.: Nonlocal boundary layer vertical diffusion in a medium-range forecast model, Mon. Weather Rev., 124, 2322-2339, 1996.

Horowitz, L. W., Walters, S., Mauzerall, D. L., Emmons, L. K., Rasch, P. J., Granier, C., Tie, X. X., Lamarque, J. F., Schultz, M. G., Tyndall, G. S., Orlando, J. J., and Brasseur, G. P.: A global simulation of tropospheric ozone and related tracers: description and evaluation of MOZART, version 2, J. Geophys. Res., 108(D24), 47874, doi:10.1029/2002JD002853, 2003.

Houyoux, M., Vukovich, J., and Brandmeyer, J. E.: Sparse Matrix Operator Kernel Emissions (SMOKE) modeling system v2.1 user manual, University of North Carolina at Chapel Hill, http: //www.smoke-model.org, accessed June 2007, 2005.

Huang, H.-C., Lin, J., Tao, Z., Choi, H., Patten, K., Kunkel, K., Xu, M., Zhu, J., Lian, X., Williams, A., Caughey, M., Wuebbles, D. J., and Wang, J.: Impacts of long-range transport of global pollutants and precursor gases on US air quality under future climatic conditions, J. Geophys. Res., 113, D19307, 
doi:10.1029/2007JD009469, 2008.

Intergovernmental Panel on Climate Change (IPCC): Atmospheric chemistry and greenhouse gases, in Climate Change 2001: The Scientific Basis, edited by: Houghton, J. T., Ding, Y., Griggs, D. J., et al., 229-288, Cambridge Univ. Press, New York, 2001.

Intergovernmental Panel on Climate Change (IPCC): Climate Change 2007: The Physical Science Basis, 996 pp, Cambridge Univ. Press, New York, 2007.

Jacob, D. J., Logan, J. A., and Murti, P. P.: Effect of rising Asian emissions on surface ozone in the United States, Geophys. Res. Lett., 26, 2175-2178, 1999.

Kain, J. S. and Fritsch, J. M.: A one-dimensional entraining/detraining plume model and its application in convective parameterization, J. Atmos. Sci., 47, 2784-2802, 1990.

Karl, T. R., Williams Jr., C. N., Quinlan, F. T., and Boden, T. A.: United States historical climatology network (HCN) serial temperature and precipitation data, Environmental science division publication, Carbon Dioxide Information and Analysis Center, Oak Ridge National Laboratory, Oak Ridge, TN, USA, 389 pp., 1990.

Knowlton, K., Rosenthal, J. E., Hogrefe, C., Lynn, B., Gaffin, S., Goldberg, R., Rosenzweig, C., Civerolo, K., Ku, J. Y., and Kinney, P. L.: Assessing ozone-related health impacts under a changing climate, Environ. Health Persp., 112, 1557-1563, 2004.

Lamarque, J.-F., Hess, P., Emmons, L., Buja, L., Washington, W., and Granier, C.: Tropospheric ozone evolution between 1890 and 1990, J. Geophys. Res., 110(D8), D08304, doi:10.1029/2004JD005537, 2005a.

Lamarque, J.-F., Kiehl, J., Brasseur, G., Butler, T., Cameron-Smith, P., Collins, W. D., Collins, W. J., Granier, C., Hauglustaine, D., Hess, P., Holland, E., Horowitz, L., Lawrence, M., McKenna, D., Merilees, P., Prather, M., Rasch, P., Rotman, D., Shindell, D., and Thornton, P.: Assessing future nitrogen deposition and carbon cycle feedback using a multi-model approach, Analysis of nitrogen deposition, J. Geophys. Res., 110, D19303, doi:10.1029/2005JD005825, 2005b.

Larkin, N. K., O’Neill, S. M., Solomon, R., Krull, C., Raffuse, S., Rorig, M., Peterson, J., and Ferguson, S. A.: The BlueSky smoke modeling framework: design, application, and performance, Int. J. Wildland Fire, in press, 2008.

Leung, L. R. and Gustafson, W. I.: Potential regional climate change and implications to US air quality, Geophys. Res. Lett., 32, L16711, doi:10.1029/2005GL022911, 2005.

Malm, W. C., Schichtel, B. A., Pitchford, M. L., Ashbaugh, L. L., and Eldred, R. A.: Spatial and monthly trends in speciated fine particle concentration in the United States, J. Geophys. Res., 109, D03306, doi:10.1029/2003JD003739, 2004.

Marenco, A., Gouget, H., Nedelec, P., Pages, J. P., and Karcher, F.: Evidence of a long-term increase in tropospheric ozone from Pic du Midi data series: consequences: positive radiative forcing, J. Geophys. Res., 99(D8), 16617-16632, 1994.

McDonald-Buller, E., Wiedinmyer, C., Kimura, Y., and Allen, D.: Effects of land use data on dry deposition in a regional photochemical model for eastern Texas, J. Air Waste Manage. Assoc., 51, 1211-1218, 2001.

Mckeen, S., Wilczak, J., Grell, G., Djalalova, I., Peckham, S., Hsie, E. Y., Gong, W., Bouchet, V., Menard, S., Moffet, R., Mchenry, J., Mcqueen, J., Tang, Y., Carmichael, G. R., Pagowski, M., Chan, A., Dye, T., Frost, G., Lee, P., and Mathur, R.: Assessment of an ensemble of seven real-time ozone forecasts over eastern North America during the summer of 2004, J. Geophys. Res., 110, D21307, doi:10.1029/2005JD005858, 2005.

McKenzie, D., O'Neill, S. M., Larkin, N. K., and Norheim, R. A.: Integrating models to predict regional haze from wildland fire, Ecol. Modell., 199, 278-288, 2006.

Mickley, L. J., Jacob, D. J., Field, B. D., and Rind, D.: Effects of future climate change on regional air pollution episodes in the United States, Geophys. Res. Lett., 31, L24103, doi:10.1029/2004GL021216, 2004.

Miranda, A. I.: An integrated numerical system to estimate air quality effects of forest fires, Int. J. Wildland Fire, 13, 217-226, 2004.

Murazaki, K. and Hess, P.: How does climate change contribute to surface ozone change over the United States?, J. Geophys. Res., 111, D05301, doi:10.1029/2005JD005873, 2006.

Nakićenović , N. and Swart, R., (Eds): IPCC Special Report on Emissions Scenarios, Cambridge University Press, New York, USA, 570 pp., 2000.

Olivier, J. G. J., Berdowski, J. J. M., Peters, J. A. H. W., Bakker, J., Visschedijk, A. J. H., and Bloos, J. P. J.: RIVM, Bilthoven,: Applications of EDGAR. Including a description of EDGAR 3.0: reference database with trend data for 1970-1995. RIVM report no. 773301001, Bilthoven, 155 pp., available at http://www.rivm.nl/bibliotheek/rapporten/410200051.html, 2001.

Racherla, P. N. and Adams, P. J.: The response of surface ozone to climate change over the Eastern United States, Atmos. Chem. Phys., 8, 871-885, 2008,

http://www.atmos-chem-phys.net/8/871/2008/.

Ratto, J., Wong, H., Liu, J., Fahy, J., Boushey, H., Solomon, C., and Balmes, J.: Effects of multiday exposure to ozone on airway inflammation as determined using sputum induction, Environ. Health Persp., 114, 209-212, 2006.

RIVM (Rijks Instituut voor Volksgezondheid en Milieu): IMAGE 2.2 CD release and documentation. The IMAGE 2.2 implementation of the SRES scenarios: A comprehensive analysis of emissions, climate change and impacts in the 21 st century, online available at:http://www.rivm.nl/image, 2002.

Salathé, E. P., Steed, R., Mass, C. F., and Zahn, P.: A high resolution climate model for the United States Pacific Northwest: Mesoscale feedbacks and local responses to climate change, J. Climate, 21, 5708-5726, 2008.

Sillman, S. and Samson, F. J.: Impact of temperature on oxidant photochemistry in urban, polluted rural and remote environments, J. Geophys. Res., 100, 11497-11508, 1995.

Spektor, D. M., Thurston, G. D., Mao, J., He, D., Hayes, C., and Lippmann, M.: Effects of single - and multiday ozone exposures on respiratory function in active normal children, Environ. Res., $55,107-122,1991$.

Staehelin, J., Thudium, J., Buehler, R., Volz-Thomas, A., and Graber, W.: Trends in surface ozone concentrations at Arosa (Switzerland)- Part A General Topics, Atmos. Environ., 28, 7587, 1994.

Steiner, A. L., Tonse, S., Cohen, R. C., Goldstein, A. H., and Harley, R. A.: Influence of future climate and emissions on regional air quality in California, J. Geophys. Res., 111, D18303, doi:10.1029/2005JD006935, 2006.

Strangers, B., Leemans, R., Eickhout, B., de Vries, B., and Bouwman, L.: The land-use projections and resulting emissions in 
the IPCC SRES scenarios as simulated by the IMAGE 2.2 model, GeoJournal, 61(n4), 381-393, available at: http://www. springerlink.com/content/p7j26720j7892r11, 2004.

Tagaris, E., Manomaiphiboon, K., Liao, K. J., Leung, L. R., Woo, J. H., He, S., Amar, P., and Russell, A. G.: Impacts of global climate change and emissions on regional ozone and fine particulate matter concentrations over the United States, J. Geophys. Res., 112, D14312, 2007.

Tao, Z., Williams, A., Huang, H. C., Caughey, M., and Liang, X. Z.: Sensitivity of US surface ozone to future emissions and climate changes, Geophys. Res. Lett., 34, L08811, doi:10.1029/2007GL029455, 2007.

Theobald, D.M.: Landscape patterns of exurban growth in the USA from 1980 to 2020, Ecol. Soc., 10(1), 32, available at: http:// www.ecologyandsociety.org/vol10/iss1/art32, 2005.

Tong, D. and Mauzerall, D.: Spatial variability of summertime tropospheric ozone over the continental United States: Implications of an evaluation of the CMAQ model, Atmos. Environ., 40, 17, 3041-3056, 2006.
US EPA: Economic growth analysis system (EGAS) version 5.0, US Environmental Protection Agency, Office of Air Quality Planning and Standards,available at: http://www.epa.gov/ttn/ ecas/egas5.htm, 2004.

Washington, W. M., Weatherly, J. W., Meehl, G. A., Semtner, A. J., Bettge, T. W., Craig, A. P., Strand, W. G., Arblaster, J., Wayland, V. B., James, R., and Zhang, Y.: Parallel Climate Model (PCM) control and transient simulations, Clim. Dynam., 16, 755-774, 2000.

Wu, S., Mickley, L. J., Leibensperger, E. M., Jacob, D. J., Rind, D., and Street, D. G.: Effects of 2000-2050 global change on ozone air quality in the United States, J. Geophys. Res., 113, D06302, doi:10.1029/2007JD008917, 2008. 